\title{
Current Opinions on Family Medicine Residency Training: Part-time vs Full-time Education
}

\section{Aile Hekimliği Uzmanlık Eğitimi Üzerine Güncel Kanaatler: Yarı Zamanlı ve Tam Zamanlı Eğitim}

\author{
Hakan Demirci ${ }^{* 1}$, Gokhan Ocakoglu ${ }^{2}$, Aykut Ardic ${ }^{l}$, Yusuf Karayurek ${ }^{l}$, Emre Yalcintas ${ }^{l}$, Fatih Ciftci ${ }^{1}$, \\ Nevruz Yildirim Topak ${ }^{1}$, Mehtap Karakulak Gomleksiz ${ }^{1}$
}

\begin{abstract}
Aim: The implementation of two different types of family medicine residency training program in Turkey, started a discussion among the academicians in our country. We planned this study to compare the opinions of domestic and foreign WONCA - Europe 2015 participants about the family medicine specialty education models based on Turkey example. Methods: Survey forms prepared in English and Turkish were submitted to the family physicians who agreed to participate in the study. Results: Participants reported two different views on the duality of family medicine residency training in Turkey. Participants from Turkey tended to have more negative opinions about the future and the sufficiency of part-time training and they demonstrated a more positive stance on the exam to select residency trainees and necessity of the scientific research and preparation of theses. Conclusions: Part-time training is a new practice for Turkey, but it has been experienced in many countries in the world for a long time. The opinions about the part-time expertise in our country seem to be negative, but it will be possible to evaluate the advantages and disadvantages of this system with the success of the doctors who will become residents with the system.
\end{abstract}

Keywords: WONCA 2015, postgraduate medical education, primary care, part-time education, thesis

\section{ÖZET}

Amaç: Türkiye'de uygulanmakta olan iki farklı aile hekimliği uzmanlık eğitim programı ülkemizdeki akademisyenler arasında tartışmaya yol açmıştır. Bu çalışmayı, yerli ve yabancı WONCA katılımcılarının, Türkiye'yi de örnek vererek aile hekimliği uzmanlık eğitim modelleri konusundaki görüşlerini karşılaştırmak için planladık. Yöntem: Araştırmaya katılmayı kabul eden aile hekimlerine İngilizce ve Türkçe hazırlanmış anket formları sunuldu. Bulgular: Kendilerine Türkiye'deki tam ve yarı zamanlı uzmanlık eğitimi hakkında kısa bir bilgi verilen katılımcılar, Türkiye'de aile hekimliği meslek eğitiminde karşılaşılan ikilem konusunda farklı görüşler bildirdiler. Yerli katılımcılar yarı zamanlı eğitimin geleceği ve yeterliliğine ilişkin daha olumsuz görüşler bildirirken, uzmanlık sınavı ve bilimsel araştırma ve tez hazırlama gerekliliği konusunda pozitif bir yaklaşım sergilediler. Sonuçlar: Dünyada "part-time (yarı zamanlı eğitim)", ülkemizde bu adla uygulamaya koyulan program ile aynı şekilde tanımlanmamış olmakla birlikte uzun süredir uygulanmaktadır. Ülkemiz için ise daha yeni bir uygulamadır. Ülkemizde bu haliyle yarı zamanlı eğitim ile ilgili olumsuz bir kanaat vardır fakat bu sistemin avantaj ve dezavantajları bu yolla uzman olan hekimlerin mesleki yeterlilikleri ölçülerek değerlendirilebilir.

Anahtar Kelimeler: WONCA 2015, mezuniyet sonrası tıp eğitimi, birinci basamak, yarı zamanlı eğitim, tez

Received / Geliş tarihi: 16.12.2016, Accepted / Kabul tarihi: 27.07.2017

${ }^{1}$ Family Medicine, University of Health Sciences Bursa Yuksek Ihtisas Training and Research Hospital, Bursa, Turkey

${ }^{2}$ Biostatistics, Uludag University, Bursa, Turkey

*Address for Correspondence / Yazışma Adresi: Hakan Demirci, Family Medicine, University of Health Sciences Bursa Yuksek Ihtisas Training and Research Hospital, Bursa-TURKEY, E-mail: drhakandemirci@hotmail.com

Demirci H, Ocakoglu G, Ardic A, Karayurek Y, Yalcintas E, Ciftci F, Topak NY, Gomleksiz MK. Current Opinions on Family Medicine Residency Training: Part-time vs Full-time Education. TJFMPC, 2017;11 (4): 221-226.

DOI: $10.21763 /$ tjfmpc. 358812 


\section{INTRODUCTION}

Family medicine residency training in Turkey is carried on with two different models. The first of these is the full-time residency training, which continues since $1983 .{ }^{1}$ This is a three-years program, and 18 months of it consists of rotations in related departments in the hospital. During the remaining 18 months, the physicians work as family physicians in the units formed within a family practice training center. Their training is thus completed. In Turkey, field training was implemented to the full-time education in $2015 .^{2-4}$ Recently, almost all of the family medicine academicians in Turkey have declared that the full-time system is the ideal training. ${ }^{5}$

The part-time assistant training model has been implemented for just two years, and it has not yet produced its first graduates. In this part-time training model, called contracted family medicine residency training, the residents are medical faculty graduates already working in the primary care units as a physician. The name of the primary care service units is "Family Medicine Centers" so physicians working in these units are named "family physicians", same as the "family medicine residents" will be named when they finish their residency. This concept causes incomprehensibility in the public and also a feeling of disvaluation among the family medicine residents. The time proposed for part-time training is six years. Part-time trainees are obliged to complete hospital rotations of 18 months during this six-year period. These residents also have an obligation to prepare a thesis like all other specialty students. ${ }^{6}$

In Turkey, a central examination system is used in the selection of specialty students in medicine. Full-time family medicine training program has made a noticeable leap as a preference in the last decade regarding the full-time training program preference. ${ }^{7}$

As mentioned above, residents for both models of family medicine education are selected with an examination called TUS (Tipta Uzmanlik Sinavi - Speciality Examination in Medicine). Even though full-time and half-time resident candidates take same examination, latter subject to a lower passing grade. Some incentive privileges are also provided for post-graduate periods of the half-time residents. Half-time residents who do not change their primary care unit within the first three years of the residency training, have a right to continue in the same unit after graduation at the end of six years.
However, full-time residents are subject to obligatory service for a year in another province after their graduation. For the time being, full-time residency requires higher grades and lasts three years, where as students are selected by a more special examination for half-time residency which lasts six years. Although time seems to be an advantage for full-time residency, the possibility to continue in their units after graduation and their relatively high payment received during their residency are the advantages of half-time assistants.

Family medicine residency training with two different models, causes a debate among the academicians in Turkey. We planned the present study to compare the views of domestic and foreign WONCA participants on family medicine residency models currently being implemented in Turkey.

\section{METHODS}

The target population of the study was Turkish and foreign participants of the WONCA 2015 Istanbul Congress $(n=3683)$. People in the convention center, lounge, and presentation hall were invited to fill out a survey. Survey forms prepared in English and Turkish were submitted to the family physicians who agreed to participate in the study. English translation was made in forward translation manner and a native English speaker checked the consistency of the phrases. The participants were asked to fill out the surveys, and those who had difficulty in understanding the questions were given additional information about the study.

In the introduction part of the survey, some preliminary information was given about family medicine education in Turkey. General characteristics of the two residency training models were also explained in this section. Following the introduction section, the participants answered a questionnaire composed of 4 likert style-questions (Table 1). The fifth question was: 'Do you agree with the opinion that part-time family medicine residency training should become more widespread?' Finally, the participants were asked if they had any additional suggestions.

\section{Statistical Analysis}

Survey results were reported as median (Inter Quartile Range-IQR) values. Mann Whitney U test were used for comparing questions scores between Turkish and foreign participants. Categorical variables were compared by Fisher Freeman Halton and Chi square test. SPSS (IBM Corp. Released 
2012. IBM SPSS Statistics for Windows, Version 21.0. Armonk, NY: IBM Corp.) software was used for statistical analysis and $\mathrm{p}<0.05$ was accepted as statistically significant.

\section{RESULTS}

One hundred and twenty-three Turkish and 89 foreign people, 212 in total, participated in our study. Only 63 of them declared their academic degrees. Title distribution were as follows among Turkish and foreign respondents respectively: professor: 4 $(6.80 \%) / 1(25 \%)$, associate professor:4 $(6.80 \%) / 0$, specialist: $25(42.40 \%) / 2(50 \%)$ and residency trainee: $26(44.10 \%) / 1(25 \%)$.The responses of the participants to the questions are shown in Table2.

While the median scores given by the Turkish physicians to Question1 and Question4 were higher than foreigners, the median scores given by the foreign physicians to Question2 and Question3 were higher than Turkish physicians. Turkish participants reported negative opinions about parttime residency training, but they had a more positive view on the necessity of residency entrance examination and thesis preparation.

When the answers given to the question 'If you were to take the family medicine residency training in Turkey, which model would you prefer?' were analyzed, opininons of Turkish and foreign participants differed significantly. While $87 \%$ (107/123) of the native participants chose the fulltime family medicine residency training model, $7.3 \%$ (9/123) preferred the contracted family medicine residency training model and 5.7\% (7/123) preferred both models. The choises of foreign participants and $\mathrm{p}$ values for each choice were as follows respectively, 52.8\% (47/89), $(\mathrm{p}<0.001)$; $32.6 \%(29 / 89), \quad(\mathrm{p}<0.001)$ and $14.6 \% \quad(13 / 89)$, $(\mathrm{p}=0.028)$. Overall $\mathrm{p}$ value was $<0.001$.

One of the participants from Hungary commented as 'No model is yet ideal. I guess we should do more GP time (Family Time). An English participant recommended full time model to himself but part time model for his wife. He also suggested more family time for the trainees. A participant from Turkey suggested that 'The ones who will be academician should prepare thesis, but there may be a thesis-free alternative' and he also added that 'Part time model may be helpful for reaching the target number of Family Medicine residents'. A family medicine residency trainee from Turkey claimed that part time training was not a traning model but it was only a continuation of postgraduate education.
Another resident suggested that continuity of care may be disrupted with the part time training since there is a period of time spent at the hospital every year.

\section{DISCUSSION}

Native and foreign participants of WONCA 2015 Istanbul Conference reported different views on the dilemma experienced in family medicine residency training in Turkey. While native participants reported more negative opinions about the future and the sufficiency of part-time training, they demonstrated a more positive stance on the exam to select residency trainees and necessity of the scientific research and preparation of thesis.

Different models of part-time medicine practices have been implemented worldwide since the 1960s in various specialties including Internal Medicine, Gynecology and Obstetrics, Surgery and Pediatrics. ${ }^{8}$ In England, where part-time education is first applied, the model had a rising trend recently. While part-time training was $8 \%$ in 2012 , this ratio increased to $11.3 \%$ in 2014 in UK. ${ }^{9}$ It is stated that this trend is also rising worldwide including Europe, North America, Asia, Australia and Africa. ${ }^{9-19}$ In Switzerland, 44 specialist degrees can be obtained with part-time courses. ${ }^{10}$ Increased interest in parttime training is linked to feminization in medical education. Because female physicians who would like to spend more time at home during birth and lactation periods prefer part-time education. One of the participants from UK suggested part time training for his wife. This recommendation is consistent with the literature knowledge. Obstetrics and Gynecology students studying part-time in UK between 1972 and 1993 are examined and it was seen that most of them completed their education about the age of 40 and $73 \%$ of them held consultant or academic positions. ${ }^{20}$ In a survey on part-time residency training, it was found that part-time residency students had better performance than fulltime students. ${ }^{13}$ In the same study, part-time trainees were found to be successful in humanistic skills. The part time residency in these examples means not being obliged to study or work in health services all the work day long but have the rest of the day off for personal purposes.

In Turkey, part-time residency training model for family medicine began to be implemented in 2014. But different than the worldwide application the part time residents can go on with their own practice as the full-time residents are not allowed. Still, in Turkey, physicians graduated from medical 


\section{Table1. The questionnaire that is asked to the participants}

Name Surname (Optional):

Country \& City:

Affiliation:

Aim: This survey is planned to evaluate perceptions of a part time family medicine training model carried out in Turkey.

\section{Information on two Family Practice Residency Models in Turkey}

A Family Medicine Residency Program is performed in two alternative models:

1. Full time residency model. This lasts 3 years. Half of the training is performed at the hospital and half is spent in family practice offices in the surroundings.

2. Part time residency model. Trainees are already family practitioners. They come to the hospital for rotations three months every year. Their residency lasts 6 years.

\begin{tabular}{|c|c|c|c|c|c|}
\hline Questions & $\begin{array}{l}\text { I totally } \\
\text { agree }\end{array}$ & I agree & Tentative & $\begin{array}{l}\text { I don't } \\
\text { agree }\end{array}$ & $\begin{array}{l}\text { I totally } \\
\text { disagree }\end{array}$ \\
\hline \multicolumn{6}{|l|}{$\begin{array}{l}\text { Do you think that part time } \\
\text { residency will be the main } \\
\text { model in Family Medicine } \\
\text { training in the future? }\end{array}$} \\
\hline \multicolumn{6}{|l|}{$\begin{array}{l}\text { 2. Do you believe that there should } \\
\text { be an examination to select } \\
\text { residency trainees? }\end{array}$} \\
\hline \multicolumn{6}{|l|}{$\begin{array}{l}\text { 3. Do you recommend 'scientific } \\
\text { research' or 'preparation of } \\
\text { Thesis' as a MUST in residency } \\
\text { training? }\end{array}$} \\
\hline $\begin{array}{l}\text { 4. Do you believe that the part time } \\
\text { residency model will be as } \\
\text { beneficial as the full time } \\
\text { residency model? }\end{array}$ & & & & & \\
\hline \multicolumn{6}{|c|}{ 5. Which model would you prefer if you were a candidate for residency in Turkey? } \\
\hline 6. Any other comments? & & & & & \\
\hline
\end{tabular}

Table 2. Comparisons of Turkish and foreigner participants' opinions on residency models

\begin{tabular}{|l|l|l|l|l|l|}
\hline & \multicolumn{2}{|c|}{ Turkish } & \multicolumn{2}{|l|}{ Foreigner } & \\
\hline & $\mathrm{n}$ & Median (IQR) & $\mathrm{n}$ & Median (IQR) & p-value \\
\hline Question1 & 122 & $5(1)$ & 89 & $3(2)$ & $<\mathbf{0 . 0 0 1}$ \\
\hline Question2 & 123 & $1(1)$ & 89 & $2(1)$ & $<\mathbf{0 . 0 0 1}$ \\
\hline Question3 & 123 & $1(1)$ & 89 & $2(3)$ & $<\mathbf{0 . 0 0 1}$ \\
\hline Question4 & 123 & $5(1)$ & 89 & $3(2)$ & $<\mathbf{0 . 0 0 1}$ \\
\hline
\end{tabular}

Question1: Do you think that part-time residency will be the main model in family medicine training in the future? Question 2: Do you believe that there should be an examination to select residency training? Question 3: Do you recommend"scientific research" or "preparation of thesis" as a MUST residency training? Question 4: Do you believe that part-time residency model will be as beneficial as the full-time residency model? IQR: Inter Quartile Range 
faculty and have no vocational training provide family medicine service. In a study comparing the satisfaction from family physicians in European countries, the satisfaction in Turkey was found to be above average. ${ }^{21}$ The effect of widespread postgraduate residency training on this satisfaction will be a subject for future research. In a study, for the part-time model, the program completion rate was found to be low although the motivation of residents was high. ${ }^{22}$ In the same study, part-time students stated that their education and research facilities were better or equal to full-time students but their continuity of care was lower. Continuity of care is one of the most important topics for family medicine. It is inevitable that physicians who still practice family medicine in Turkey will have problems about continuity of care during their parttime education. Part-time training is a new practice in Turkey and is implemented only in Family Medicine training, which is slightly different from its counterparts in other countries. The success of the family medicine residency training will probably open the debate on the applicability of this model to other branches. Part-time education is a complicated method for the organizers of the training due to disruption of the service. Part-time training can be implemented as a rotating shift in the daytime, or it can also be applied as one month off and one month on fashion. ${ }^{8}$ There is the problem of finding a partner in both approach. In the part-time education in our country, the family physicians attend rotations in the hospital during three month periods throughout the year. While the ones who can be substituted by a partner in the family medicine unit are lucky, those who can't find a partner face some financial loss because substituent physician is called for duty from the community health center.

In the regulations on specialties in medicine, the students are obliged to prepare a thesis to earn a degree. Thus, at least one scientific research is compulsory. There is an obligation of a thesis in family medicine as in all other specialty branches. In the study, the response of the native physicians to the question of the necessity of scientific research and a thesis was "yes" at a significantly high level. In the WONCA tree, the roots of family medicine are fed from science. ${ }^{23}$ Family physicians should be a pioneer in the field of informatics and benefiting from science. thesis and scientific research should be perceived as a chance, not as an obligation in the family medicine residency training course. The comment in the study suggesting thesis-free options for the residency programmes should also be discussed.
When the physicians were asked which model they would prefer if they were a candidate for family medicine training, while Turkish doctors preferred full-time training at a rate of $87 \%$, foreign participants found full-time training appropriate for themselves at a rate of $52.8 \%$. High preference for full-time education by our native physicians can be associated with the fact that they are still in this model but foreigners were neutral on this subject. It has been shown that part-time model was supported by $60-90 \%$ of the physicians in abroad. ${ }^{8}$ Similarly, our study suggests that there would not be an absolute rejection of part-time model. It may have gain acceptance in the future.

\section{Limitations}

A significant limitation in the survey is the limited number of participants. In a limited time, we have been able to reach small number of volunteers. It can be predicted that the subjects' gender, the time they spent in the field, or the institutions they work and similar details may significantly affect personal evaluations. So, it is not appropriate to make generalizations about the results obtained. In addition, the application of part-time residency is a very new concept in terms of creating a conviction about the subject for our country.

\section{CONCLUSIONS}

Two different models of family medicine residency training are still implemented in Turkey. Part-time training is a new practice for Turkey, but it has been experienced in many countries in the world for a long time. The opinions about the part-time residency training in our country seem to be negative, but it will be possible to evaluate the advantages and disadvantages of this system with the success of the doctors who will become residents within the system.

\section{Acknowledgement}

The authors thank to Mrs Nazli Demirci (Philologist) for her contribution to the study.

Funding: No funding.

Disclosures: There is no conflict of interest.

\section{REFERENCES}

1. Tababet Uzmanlık Tüzüğünde Değişiklik Yapılmasına İlişkin Tüzük. (1983). TC Resmi Gazete 18230, 21.11.1983. 
2. Katip Çelebi Aile Sağlığı Merkezleri, Hem Sağlık Hizmeti, Hem Eğitim Veriyor. http://www.haberler.com/katip-celebi-ailesagligi-merkezleri-hem-saglik-8322558-haberi. Accessed: 07.04.2017

3. Konya'da Eğitim Aile Sağlığı Merkezi Açıldı. http://www.yenimeram.com.tr/konyada-egitimaile-sagligi-merkezi-acildi-149096.htm. Accessed: 07.04.2017

4. Asistan doktorlar hem hizmet veriyor, hem eğitim görüyor. http://www.milliyet.com.tr/asistan-doktorlarhem-hizmet-veriyor-bursa-yerelhaber1028767. Accessed: 07.04.2017

5. Türkiye Aile Hekimliği Akademisyenleri Bildirisi: Yarı Zamanlı Uzmanlığa Hayır. http://www.tahud.org.tr/guncel/dernekhaber/turkiye-aile-hekimligi-akademisyenleribildirisi-yari-zamanli-uzmanliga-hayir-/642. Accessed: 24.08.2016.

6. Sözleşmeli Aile Hekimlerine Verilecek Aile Hekimliği Uzmanlık Eğitimi Usul Ve Esasları http://www.thsk.gov.tr/dosya/mevzuat/genel_ni telikli_yazilar/sahu_yonerge.pdfAccessed: 07.04.2017

7. Uzm Dr Fatih batı: TUS Kontenjanları ve Branşların Puan Analizi https://hipokratinyeri.wordpress.com/2014/12/ 23/uzm-dr-fatih-bati-tus-kontenjanlari-vebranslarin-puan-analiziAccessed: 24.08.2016.

8. Gordon MB, McGuinness GA, Stanton BF, Brooks S, Chiang VW, Vinci R, Sectish TC. Part-time training in pediatric residency programs: principles and practices. Pediatrics, 2008;122(4), e938-e944.

9. Harries, R. L., Gokani, V. J., Smitham, P., \& Fitzgerald, J. E. F. (2016). Less than full-time training in surgery: a cross-sectional study evaluating the accessibility and experiences of flexible training in the surgical trainee workforce. BMJ open, 6(4), e010136.

10. Heuss LT, Haenggeli C. Open access to parttime specialist trainingthe Swiss experience. Swiss Med Wkly 2003;133:263-6.

11. Jerg-Bretzke L, Limbrecht K. Where have they gone? A discussion on the balancing act of female doctors between work and family. GMS Z Med Ausbild 2012;29:Doc 19.

12. Kaderli R, Guller U, Muff B, et al. Women in surgery: a survey in Switzerland. Arch Surg 2010;145:1119-21.

13. Carling PC, Hayward K, Coakley EH, et al. Part-time residency training in internal medicine: analysis of a ten-year experience. Acad Med 1999;74:282-4.

14. Saalwachter AR, Freischlag JA, Sawyer RG, et al. Part-time training in general surgery: results of a web-based survey. Arch Surg 2006;141:977-82.

15. Nomura K, Yamazaki Y, Gruppen LD, et al. The difficulty of professional continuation among female doctors in Japan: 6 Harries RL, et al. BMJ Open 2016;6:e010136. doi:10.1136/bmjopen-2015-010136 Open Access Downloaded from http://bmjopen.bmj.com/ on December 13, 2016 - Published by group.bmj.com a qualitative study of alumnae of 13 medical schools in Japan. BMJ Open 2015;5:e005845.

16. Mahady SE. Adding flexibility to physician training. Med J Aust 2011;194:460-2.

17. Henry A, Clements S, Kingston A, et al. In search of work/life balance: trainee perspectives on part-time obstetrics and gynaecology specialist training. BMC Res Notes 2012;5:19.

18. McDonald RE, Jeeves AE, Vasey CE, et al. Supply and demand mismatch for flexible (parttime) surgical training in Australasia. Med J Aust 2013;198:423-5.

19. Gardner SV, James MF, Evans NR. Gender issues among South African anaesthetists. S Afr Med J 2002;92:732-6.

20. Davies M, Eaton J. Flexible training under the new deal. BMJ 2002;324:1111-2.

21. Aktürk Z, Ateşoğlu D, Çiftçi E. Patient satisfaction with family practice in Turkey: Three-year trend from 2010 to 2012. Europan Journal of General Practice, 2015;21: 238-45.

22. Henry A, Clements S, Kingston A, Abbott, J. In search of work/life balance: trainee perspectives on part-time obstetrics and gynaecology specialist training. BMC research notes. 2012;5(1), 1.

23. Hummers-Pradier E, Beyer M, Chevallier P, et al. The Research Agenda for General Practice/Family Medicine and Primary Health Care in Europe. Part 1. Background and methodology1. The European journal of general practice 2009;15(4), 243-50. 